\title{
Development and Sensory Evaluation of Beverages having High Antioxidant Activity
}

\author{
Gopika Puri*, Balwinder Sadana and Neerja Singla \\ Department of Food and Nutrition, College of Home Science, PAU, Ludhiana, Punjab, India \\ *Corresponding author
}

\begin{tabular}{|c|c|}
\hline & A B S T R A C T \\
\hline & \multirow{7}{*}{$\begin{array}{l}\text { Citrus fruits and juices are valuable part of healthy and nutritious diet. Beverages from } \\
\text { fruits are low cost and are very refreshing. Fruit beverage gives all the plant nutrients e.g. } \\
\text { phenols, important vitamins, minerals and fiber. Low cost beverages with high nutritional } \\
\text { values can be made from fruits which plays a significant role in human diet. Four } \\
\text { beverages namely- amla beverage, grapefruit beverage, kinnow beverage and orange } \\
\text { beverage were prepared and were subjected to sensory evaluation. Grapefruit due to its } \\
\text { bitter taste is not palatable for direct consumption, same with amla fruit due to its } \\
\text { astringency it is not consumed, hence processing is required. The fruit beverages were } \\
\text { chemically analyzed and suitable formulation was made. The nutritional analysis revealed } \\
\text { that the beverages are rich in vitamins and antioxidant content. Orange beverage got the } \\
\text { highest moisture content i.e. } 97.0 \pm 1.0 / 100 \mathrm{ml} \text {, whereas grapefruit beverage had the } \\
\text { highest content of crude protein } 0.8 \pm 0.05 / 100 \mathrm{ml} \text { and amla beverage got the highest } \\
\text { vitamin C content } 780.2 \mathrm{mg} \pm 1.3 / 100 \mathrm{ml} \text { than grapefruit, kinnow and orange beverage. } \\
\text { The study evaluated the appearance, colour, texture, flavour, overall acceptability of fresh } \\
\text { fruit beverages. The prepared beverages were sensory evaluated by a panel of judges using } \\
9 \text { point hedonic scale. }\end{array}$} \\
\hline Keywords & \\
\hline & \\
\hline & \\
\hline Article Info & \\
\hline $\begin{array}{l}\text { Accepted: } \\
\text { 17 September } 2017 \\
\text { Available Online: } \\
10 \text { November } 2017\end{array}$ & \\
\hline & \\
\hline
\end{tabular}

\section{Introduction}

Citrus fruits have high content of vitamin $\mathrm{C}$, carotenoids and phenolic content that play important role in the nutritional and organoleptic properties contributing to color, astringency, flavor and bitterness (Xu et al., 2008). Fruits are healthy foods as they are rich in antioxidants, vitamins, dietary fiber, minerals and do not contain any dairy allergens like casein and lactose (Lucknow and Delahunty, 2004). Beverages made from fruits and vegetables are important in our diet as they are pleasant, satisfying and having refreshing qualities. Carbonated beverages do not contain any nutrients and are expensive.
So there is a plenty of scope for the development of low cost beverages of high nutritional value using locally available fruits and vegetables (Sundharani et al., 2013). Using seasonal fruits low cost beverages of high nutritional value can be developed. Fruit juice also serves as a good medium for probiotics (Tuorila and Cardello, 2002). Approximately $65 \%$ of the citrus produced in United States is processed into juices, however 95-96\% of Florida's orange crop is used for juice (USDA, 2006). The vitamin C and flavonoids level vary depending upon the species, place of growth, harvesting period, 
storage and also on the processing technique (Franke et al., 2003). Consumption of fruit juices is also recommended for prevention of cardiovascular diseases, liver diseases etc as natural juices provide a high percentage of vitamins and minerals. Flavonoids in fruits exhibit biological properties including antiallergic, antiviral, anti-atherogenic, antiinflammatory, inhibition of blood clots, cardio protective and antitumor activity. Sensory evaluation is necessary to build a relationship between the product characteristics and the consumer. Appearance, taste, color and texture are the important sensory attributes (Escribano et al., 2010).

\section{Materials and Methods}

\section{Procurement}

Commonly consumed fruits were taken namely- Amla, grapefruit, kinnow and orange were procured from the local market of Ludhiana city. Fruits were purchased and checked for any infestation or damage. They were then used for juice extraction.

\section{Formulation and development of the beverages}

Four antioxidant rich beverages namely amla, grapefruit, kinnow and orange beverages were developed. The standard procedures used for product development is mentioned in Table 1.

\section{Sensory and organoleptic evaluation of prepared beverages}

The beverages were prepared in the Food Laboratory of Department of Food and Nutrition, Punjab Agricultural University, Ludhiana. The four antioxidant rich beverages were first standardized at different levels. Each of the developed beverages for hyperlipidemic subjects was compared treatment wise by ten trained panelists including faculty of department of Food and Nutrition of Punjab Agricultural University using 9 point hedonic scale for different parameters such as appearance, color, texture, aroma, taste and overall acceptability (Larmond, 1970). The samples were then given to the panelists with an evaluation form.

They were asked to taste one sample at a time, and record their responses allowing time between samples so that the tasters can record their opinion. Two variations of each fruit beverage were made. The composition of the different beverages was subjected to sensory evaluation as presented in Table 1 .

\section{Nutritional analysis of the prepared beverages}

The developed beverages were then subjected to nutritional analysis for proximate, vitamins and antioxidant content using standard procedures.

\section{Proximate composition}

Proximate composition like Moisture, Crude Protein, Crude Fat, Crude Fiber, Crude Ash and Carbohydrates were analyzed using standard procedures suggested by AOAC (2000).

\section{Vitamins}

Vitamins like Ascorbic Acid was analyzed using standard procedures given in AOVC (1996), $\beta$-carotene and Total carotene was estimated by column chromatography method as explained by Rangana (1995).

\section{Antioxidant activity}

DPPH activity by (Sreeramulu et al., 2009), total flavonoid content by (Woisky and Salatino, 1998) and total phenolic content by Singleton and Rossi (1965). 


\section{Statistical analysis}

The data generated from the performas of sensory scores were statistically analyzed using Tukey test and paired t-test was applied for the nutritional attributes. The values are expressed as Mean \pm SD (Standard deviation).

\section{Results and Discussion}

\section{Proximate content of the developed beverages}

The result of the proximate composition of the four beverages is shown in Table 2. The four beverages showed a high content of moisture level ranging from $86.0 \pm 1.0$ to $97.0 \pm 1.0 / 100 \mathrm{ml}$ which indicated that the beverages were good source for quenching thirst. The other nutrients like crude protein, crudefat and carbohydrates are reduced due to the high intake of moisture in it. The carbohydrate content in fruit beverages ranging from $2.1 \pm 0.7$ to $8.1 \pm 1.7 / 100 \mathrm{ml}$ indicated that they are moderate sources of sugars. The low levels of crude protein and fat indicates that fruits are not good source of these nutrients (Nnam and Nojku, 2005). Ogbonna et al., (2013) had also reported that orange juice, pineapple juice and paw juice had $85.85 \pm 0.04,83.99 \pm 0.07,82.74 \pm 0.10$ moisture, $0.74 \pm 0.03,0.62 \pm 0.01,0.43 \pm$ 0.03 crude protein, $0.21 \pm 0.01,0.12 \pm 0.00$, $0.35 \pm 0.02$ crude fat, $0.24 \pm 0.01,0.16 \pm 0.03$, $0.21 \pm 0.01$ crude fiber and $11.54 \pm$ $0.03,12.67 \pm 0.05,14.87 \pm 0.07 \mathrm{~g} / 100 \mathrm{ml}$ carbohydrates, respectively.

\section{Vitamin content of the developed beverages}

Among the developed fruit beverages high ascorbic acid was observed in amla beverage i.e.780.2 $\pm 1.3 \mathrm{mg}$ followed by orange beverage $(40.4 \pm 1.4 \mathrm{mg}$ ), grapefruit beverage $(36.5 \pm 0.5 \mathrm{mg})$ and kinnow beverage $(30.3 \pm$ $0.5 \mathrm{mg} / 100 \mathrm{ml})$. The higher amount of ascorbic acid also indicates that beverages increases the iron absorption in the body as well as the formation of intracellular protein collagen. The $\beta$-carotene content was high in kinnow beverage i.e. $0.03 \pm 0.01 / 100 \mathrm{ml}$ whereas total carotenoid content was high in orange beverage i.e. $1.4 \pm 0.1 / 100 \mathrm{ml}$ and lowest in amla beverage i.e. $0.4 \pm 0.5 / 100 \mathrm{ml}$ (Table 3).

\section{Antioxidant activity of the developed beverages}

Among various citrus fruits analyzed the total phenolic content of orange beverage was highest i.e. $77.6 \mathrm{mg} \pm 0.2$ and lowest in grapefruit beverage $50.0 \mathrm{mg} \pm 1.0 / 100 \mathrm{ml}$. The total flavonoid content was very high in amla beverage i.e. $179.0 \pm 1.3 \mathrm{mg} / 100 \mathrm{ml}$, whereas the total flavonoid content among the citrus beverages ranged between $22.6 \pm$ 0.2 to $78.5 \pm 0.5 \mathrm{mg} / 100 \mathrm{ml}$. A study on citrus fruit juices indicated the flavonoid content for grapefruit juice was $97.31 \pm 5.49$ $\mathrm{mg} / 100 \mathrm{ml}$ (Guimaraes et al., 2010). The DPPH scavenging activity was highest in amla beverage i.e. $84.78 \%$ followed by citrus fruit beverages i.e. grapefruit beverage having 81.3 , orange beverage with 78.1 and kinnow beverage with $66.3 \%$, respectively (Table 4).

\section{Sensory evaluation of the antioxidant rich beverages}

The sensory scores for the antioxidant rich beverages are presented in Table 5. The appearance of the beverage $\mathrm{T} 2$ got the highest score which was blend of amla juice, ginger and cumin seeds. Beverage prepared using grapefruit and kinnow in the ratio of 1:2 (T2) got the highest score in appearance i.e.7.4 \pm 0.01 . The colour of grapefruit beverage T3 got the highest score which is a blend with kinnow juice in the ratio 2:1. In kinnow beverage $\mathrm{C}$ and $\mathrm{T} 1$ got the same score for color whereas in orange beverage $\mathrm{T} 1$ and $\mathrm{T} 2$ got the same score i.e. $8.3 \pm 0.1$. 
Table.1 Development of the beverages

\begin{tabular}{|l|l|l|l|}
\hline S. No. & $\begin{array}{l}\text { Name of the } \\
\text { beverage }\end{array}$ & Ingredients & Method \\
\hline 1. & Amla beverage & $\begin{array}{l}\text { Amla (after destonning)- } \\
\text { 150g, Mint leaves-3gms, } \\
\text { Sugar-30g,Water-100 ml } \\
\text { thoroughly. Then amla was destoned and } \\
\text { mint leaves were chopped. Both the } \\
\text { ingredients were then blend together by } \\
\text { adding water in the grinder. Then the } \\
\text { juice was filtered and sugar syrup was } \\
\text { added. }\end{array}$ \\
\hline 2. & $\begin{array}{l}\text { Grapefruit } \\
\text { beverage }\end{array}$ & $\begin{array}{l}\text { Grapefruit (after peel)- 200 } \\
\text { g, Kinnow (after peel)- 200 } \\
\text { g, Sugar -30g. }\end{array}$ & $\begin{array}{l}\text { Grapefruit was sliced and juice was } \\
\text { extracted with the help of juicer. Kinnow } \\
\text { was also peeled and white covering of the } \\
\text { kinnow pieces was removed and the pulp } \\
\text { was used for extracting the juice. The } \\
\text { grapefruit juice was taken in a bowl and } \\
\text { mixed with kinnow juice in a ratio 1:1. } \\
\text { Then the sugar syrup was added to it. }\end{array}$ \\
\hline 3. & Kinnow beverage & $\begin{array}{l}\text { Kinnow (after peel)-350 g, } \\
\text { Sugar-30g, Black salt- } \\
\text { pinch }\end{array}$ & $\begin{array}{l}\text { Kinnow was peeled, the outer covering } \\
\text { and the seeds were removed. The pulp } \\
\text { was used for extracting the juice. Sugar } \\
\text { was added and mixed well till the sugar } \\
\text { dissolved. }\end{array}$ \\
\hline 4. & Orange beverage & $\begin{array}{l}\text { Orange (after peel)-350 g, } \\
\text { Ginger - 3g, Sugar- 30g }\end{array}$ & $\begin{array}{l}\text { Orange was peeled, the outer covering } \\
\text { and the seeds were removed. A slice of } \\
\text { ginger was added with the pulp for } \\
\text { extracting the juice. Sugar was added and } \\
\text { mixed well till the sugar dissolved. }\end{array}$ \\
\hline
\end{tabular}

Table.2 Proximate composition of the developed fruit beverages (g/ 100ml fresh weight basis)

\begin{tabular}{|l|c|c|c|c|c|c|}
\hline Fruits & Moisture & $\begin{array}{c}\text { Crude } \\
\text { Protein }\end{array}$ & Crude Fat & $\begin{array}{c}\text { Crude } \\
\text { Fiber }\end{array}$ & Ash & $\begin{array}{c}\text { Available } \\
\text { Carbohydrates }\end{array}$ \\
\hline Amla & $86.0 \pm 1.0$ & $0.6 \pm 0.2$ & $0.01 \pm 0.005$ & $4.5 \pm 0.4$ & $0.8 \pm 0.2$ & $8.1 \pm 1.7$ \\
\hline Grapefruit & $95.3 \pm 0.6$ & $0.8 \pm 0.05$ & $0.2 \pm 0.1$ & $1.2 \pm 0.1$ & $0.4 \pm 0.2$ & $2.1 \pm 0.7$ \\
\hline Kinnow & $90.3 \pm 2.5$ & $0.7 \pm 0.2$ & $0.1 \pm 0.09$ & $0.4 \pm 1.0$ & $0.2 \pm 0.3$ & $6.2 \pm 0.5$ \\
\hline Orange & $97.0 \pm 1.0$ & $0.1 \pm 0.05$ & $0.1 \pm 0.05$ & $0.13 \pm 0.05$ & $0.4 \pm 0.02$ & $2.3 \pm 1.1$ \\
\hline
\end{tabular}

Values are expressed as mean $\pm \mathrm{SD}$

Table.3 Vitamin content of the developed fruit beverages (per 100ml fresh weight basis)

\begin{tabular}{|l|c|c|c|}
\hline \multicolumn{1}{|c|}{ Fruits } & Ascorbic Acid (mg) & $\boldsymbol{\beta}$-carotene $(\boldsymbol{\mu g})$ & Total Carotenoids $(\boldsymbol{\mu g})$ \\
\hline Amla & $780.2 \pm 1.3$ & $0.02 \pm 0.01$ & $0.4 \pm 0.5$ \\
\hline Grapefruit & $36.5 \pm 0.5$ & $0.02 \pm 0.01$ & $0.1 \pm 0.01$ \\
\hline Kinnow & $30.3 \pm 1.5$ & $0.03 \pm 0.01$ & $1.3 \pm 0.05$ \\
\hline Orange & $40.4 \pm 1.4$ & $0.1 \pm 0.01$ & $1.4 \pm 0.1$ \\
\hline
\end{tabular}

Values are expressed as mean \pm SD 
Table.4 Antioxidant activity of the developed beverages (per 100ml fresh weight basis)

\begin{tabular}{|l|c|c|c|}
\hline \multicolumn{1}{|c|}{ Fruits } & $\begin{array}{c}\text { Total Phenolic } \\
\text { Content }(\mathbf{m g})\end{array}$ & $\begin{array}{c}\text { Total Flavonoid } \\
\text { Content }(\mathbf{m g})\end{array}$ & $\begin{array}{c}\text { DPPH Radical Scavenging } \\
\text { Activity (\% Inhibition) }\end{array}$ \\
\hline Amla & $96.0 \pm 1.3$ & $179.0 \pm 1.3$ & $84.78 \pm 0.9$ \\
\hline Grapefruit & $50.0 \pm 1.0$ & $78.5 \pm 0.5$ & $81.3 \pm 0.1$ \\
\hline Kinnow & $74.1 \pm 1.0$ & $20.2 \pm 0.9$ & $66.3 \pm 1.5$ \\
\hline Orange & $77.6 \pm 0.2$ & $22.6 \pm 0.2$ & $78.1 \pm 0.1$ \\
\hline
\end{tabular}

Values are expressed as mean \pm SD

Table.5 Sensory evaluation of the developed beverages

\begin{tabular}{|l|l|l|l|l|l|}
\hline Treatments & Appearance & Color & Texture & Flavor & Overall acceptability \\
\hline Amla beverage \\
\hline Control (C) & $7.0 . \pm 0.05^{\mathrm{a}}$ & $6.5 \pm 0.1^{\mathrm{b}}$ & $7.3 \pm 0.01^{\mathrm{a}}$ & $6.4 \pm 0.01^{\mathrm{c}}$ & $6.8 \pm 0.005^{\mathrm{b}}$ \\
\hline T1 & $7.6 \pm 0.3^{\mathrm{b}}$ & $7.4 \pm 0.1^{\mathrm{a}}$ & $7.3 \pm 0.01^{\mathrm{a}}$ & $7.2 \pm 0.005^{\mathrm{a}}$ & $7.3 \pm 0.005^{\mathrm{a}}$ \\
\hline T2 & $8.0 \pm 0.1^{\mathrm{a}}$ & $7.2 \pm 0.06^{\mathrm{a}}$ & $7.2 \pm 0.005^{\mathrm{a}}$ & $6.7 \pm 0.005^{\mathrm{b}}$ & $7.3 \pm 0.005^{\mathrm{a}}$ \\
\hline Grapefruit beverage \\
\hline Control (C) & $7.0 \pm 0.1^{\mathrm{a}}$ & $7.0 \pm 0.1^{\mathrm{a}}$ & $7.0 \pm 0.1^{\mathrm{a}}$ & $6.3 \pm 0.05^{\mathrm{b}}$ & $6.8 \pm 0.1^{\mathrm{b}}$ \\
\hline T1 & $7.2 \pm 0.1^{\mathrm{a}}$ & $7.1 \pm 0.05^{\mathrm{a}}$ & $7.0 \pm 0.1^{\mathrm{a}}$ & $6.9 \pm 0.05^{\mathrm{a}}$ & $7.2 \pm 0.1^{\mathrm{a}}$ \\
\hline T2 & $7.4 \pm 0.01^{\mathrm{a}}$ & $7.3 \pm 0.1^{\mathrm{a}}$ & $7.0 \pm 0.1^{\mathrm{a}}$ & $7.2 \pm 0.1^{\mathrm{a}}$ & $7.0 \pm 0.01^{\mathrm{a}}$ \\
\hline Kinnow beverage & $8.0 \pm 0.1^{\mathrm{a}}$ & $8.5 \pm 0.01^{\mathrm{a}}$ & $8.5 \pm 0.01^{\mathrm{a}}$ & $8.4 \pm 0.005^{\mathrm{a}}$ & $8.5 \pm 0.01^{\mathrm{a}}$ \\
\hline Control (C) & $8.6 \pm 0.01^{\mathrm{ab}}$ & $8.5 \pm 0.01^{\mathrm{a}}$ & $8.4 \pm 0.006^{\mathrm{a}}$ & $8.2 \pm 0.1^{\mathrm{a}}$ & $8.4 \pm 0.005^{\mathrm{ab}}$ \\
\hline T1 & $8.4 \pm 0.01^{\mathrm{b}}$ & $8.0 \pm 0.1^{\mathrm{a}}$ & $7.8 \pm 0.006^{\mathrm{c}}$ & $7.4 \pm 0.005^{\mathrm{b}}$ & $8.1 \pm 0.005^{\mathrm{b}}$ \\
\hline T2 & $8.2 \pm 0.01^{\mathrm{a}}$ & $8.2 \pm 0.01^{\mathrm{a}}$ & $8.0 \pm 0.1^{\mathrm{a}}$ & $8.4 \pm 0.005^{\mathrm{a}}$ & $8.2 \pm 0.05^{\mathrm{a}}$ \\
\hline Orange beverage & $8.0 \pm 0.1^{\mathrm{a}}$ & $8.3 \pm 0.1^{\mathrm{a}}$ & $8.1 \pm 0.1^{\mathrm{a}}$ & $7.7 \pm 0.01^{\mathrm{ab}}$ & $8.0 \pm 0.005^{\mathrm{a}}$ \\
\hline Control (C) & $8.0 \pm 0.1^{\mathrm{a}}$ & $8.3 \pm 0.1^{\mathrm{a}}$ & $8.1 \pm 0.1^{\mathrm{a}}$ & $7.4 \pm 0.01^{\mathrm{b}}$ & $7.9 \pm 0.05^{\mathrm{b}}$ \\
\hline T1 & $8.0 \pm 0.1^{\mathrm{a}}$ &
\end{tabular}

Values are expressed as means \pm SD, Significant at $5 \%,{ }^{\text {a-c }}$ Means within each row with different superscripts are significantly $(\mathrm{p} \leq 0.05)$ different

C: Amla juice; T1: Amla juice + mint leaves + sugar; T2: Amla juice+ ginger+ cumin seeds.

C: Grapefruit juice; T1: Grapefruit juice + kinnow juice $(1: 1)+$ sugar; T2: Grapefruit juice+ kinnow juice (1:2) + sugar

C: Kinnow juice; T1: Kinnow juice+ cumin seeds+ black salt; T2: Kinnow juice + honey + lemon

C: Orange juice; T1: Orange juice+ ginger +sugar; T2: Orange juice + lemon + sugar

Scores (Nine point hedonic scale, 9- Excellent, 8- Extremely good, 7- Very good, 6- Moderately good, 5- Good, 4-

Fair, 3- Very fair, 2- Poor, 1- Very poor) 
Fig.1 Sensory evaluation of the developed beverages

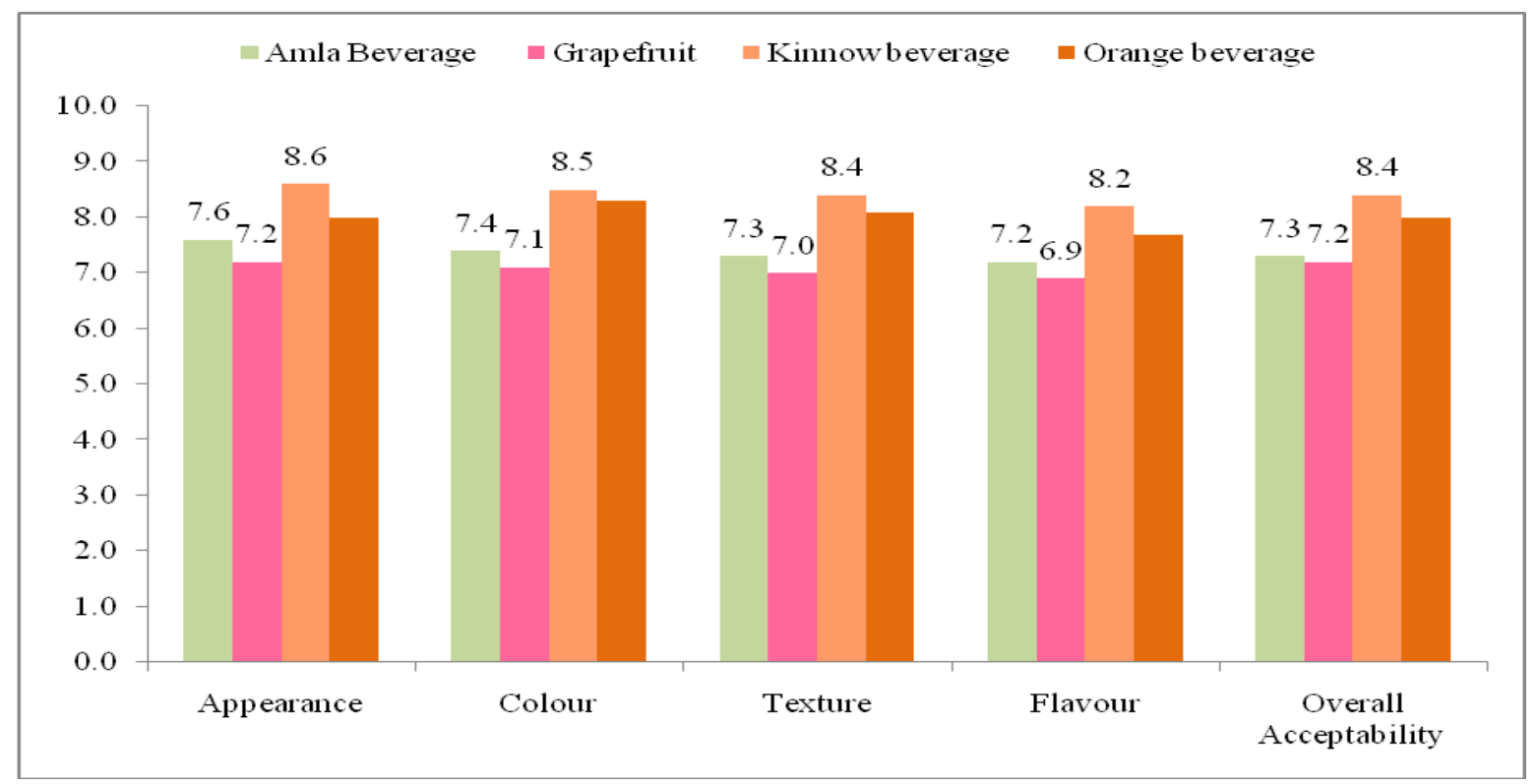

In case of texture of the beverages amla beverage, grapefruit and orange beverages scored almost the same. For the parameter flavour in kinnow and orange beverage $\mathrm{C}$ got the highest score as it is the $100 \%$ fruit juice and in amla beverage the $\mathrm{C}$ got the lowest score of $6.4 \pm 0.01$ (Fig. 1). Amla due to its astringent taste, was not palatable for direct consumption, so processing is required (Mishra et al., 2010). Hundred percent of kinnow beverage $(\mathrm{C})$ and orange beverage $(\mathrm{C})$ scored the highest in overall acceptability i.e. $8.5 \pm 0.01$ and $8.2 \pm 0.05$ whereas amla beverage (C) and grapefruit (C) got the lowest score i.e. $6.8 \pm 0.005$ and $6.8 \pm 0.1$ respectively. Blending of fruit juices is practiced to overcome the high cost of some exotic fruits, scarcity or seasonal availability, balancing of strong flavors, astringency, high acidity, bitterness and stabilizing colour (Bates et al., 2001).

The study concluded that, the four beverages were prepared namely amla beverage, grapefruit beverage, kinnow beverage and orange beverage which are rich sources of vitamins, minerals, antioxidants and fibers and are well relished by everyone. T1 was acceptable for supplementation among all the four prepared beverages. Amla beverage had the highest antioxidant activity i.e. $84.78 \%$ and among the citrus beverages grapefruit had the highest antioxidant activity i.e. $81.3 \%$.

The blending of fruit juices are done to increase their acceptability and nutritional quality of fruits which cannot be eaten raw like amla due to its astringent property need to get processed and grapefruit due to its sour flavour need to be blended with other juices. The fresh made seasonal beverages provide more cost-effective alternative to meet daily recommended values.

\section{References}

AOAC (2000) Official methods of analysis, $13^{\text {th }}$ edition, Association of Official Analytical Chemist, Washington DC.

AOVC (1996) Methods of vitamin assay, Association of Vitamin Chemists Inc. (Ed.). Pp. 306-12. Interscience Publishers.

Bates R P, Morris J R and Crandall P G (2001) Principles and practices of 
small-and medium-scale fruit juice processing. FAO agricultural services bulletin. Pp. 1-221.

Escribano S, Sanchez FJ and Lazaro A (2010) Establishment of a sensory characterization protocol for melon (Cucumis melo L.) and its correlation with physical-chemical attributes: indications for future genetic improvements. Eur Food Res Technol 231:611-21.

Franke AA, Laurie J, Custer, Arakaki C and Murphy P S (2003) Vitamin C and flavonoid levels of fruits and vegetables consumed in Hawaii. J Food Comp Anal 17(4):17-35.

GH Xu, JC Chen, DH Liu, YH Zhang, P Jiang and XQ Ye, "Minerals, Phenolic Compounds, and Antioxidant Capacity of Citrus Peel Extract by Hot Water." J Food Sci 73:11-18 2008.

Guimaraes R, Barros L, Barreira JCM, Sousa M J, Carvalho AM and FerreiraI ICFR (2010) Targetting excessive free radicals with peels and juices of citrus fruits: grapefruit, lemon, lime and orange. Food Chem Toxicol 48: 99-106.

Larmond E (1970) Methods of sensory evaluation of food. Can Deptt Agric Pubs Pp.1284.

Lucknow T and Delahunty C (2004) Which juice is "healthier"? A consumer study of probiotics non-dairy juice drinks. Food quality and Preference 15:751759.

Mishra V P, Mishra and Rao G K (2010) Process and product standardization for the development of amla bar, beverage. Fd World 37: 58-60.
Nnam NM and Njoku IE (2005) Production and evaluation of nutrient and sensory properties of juices made from citrus fruits. Nigerian J Nutr Sc., 26:62-66.

Ogbonna AC, Abuajah CI and Ekpe GE (2013) A comparative study of the nutritive factors and sensory acceptanance of juices from selected Nigerian fruits. Croation $J$ Food Technol, Biotechnolo 8: 47-51.

Ranganna S (2002) Handbook of analysis and quality control for fruit and vegetable products. Tata Mc Graw Hill Pub. Co. Ltd. New Delhi.

Singleton VL and Rosssi JA (1965) Colorimetry of total phenolics with phosphomolybdic-phototungstic acid reagents. Am J Enol Vitic 16: 144-58.

Sreeramulu D, Reddy CV and Raghunath M (2009) Antioxidant activity of commonly consumed cereals, millets, pulses and legumes in India. Ind $J$ Biochem Biophy 46: 112-15.

Sundharani N, Hiremath US and Shivleela HB (2013) Standardization of ash gourd and amla based instant juice and soup mixes. Global J Bio Agric Health sci 2(1):10-19.

Tuorila H and Cordello A V (2002) Consumer responses to an off- flavor in juice in the presence of specific health claims. Food quality and Preference 13:561.569.

USDA (2006) Situation and outlook for citrus.

Woisky R and Salatino A (1998) Analysis of propolis: some parameters and procedures for chemical quality control. J Apic Res 37: 99-105.

\section{How to cite this article:}

Gopika Puri, Balwinder Sadana and Neerja Singla. 2017. Development and Sensory Evaluation of Beverages having High Antioxidant Activity. Int.J.Curr.Microbiol.App.Sci. 6(11): 22532259. doi: https://doi.org/10.20546/ijcmas.2017.611.267 